\title{
IMPLEMENTASI NILAI-NILAI BHINEKA TUNGGAL IKA PADA SISWA KELAS VII SMP NEGERI 1 SURAKARTA PADA TAHUN PELAJARAN 2016/2017
}

\author{
Artikel \\ Penulis \\ Umi Setyaningsih $^{1}$ \\ Mahasiswa S2 Program Studi PKn \\ Program Pasca Sarjana UNS Surakarta \\ Yulianto Bambang Setyadi ${ }^{2}$ \\ Mahasiswa S3 Program Studi Evaluasi dan Penelitian pendidikan \\ Program Pasca sarjana UNY Yogyakarta
}

\begin{abstract}
ABSTRAK
Penelitian ini bertujuan untuk mendeskripsikan proses implementasi nilainilai Bhineka Tunggal Ika pada Siswa Kelas VII SMP Negeri 1 Surakarta Tahun Pelajaran 2016/2017, berbagai macam hambatan yang dihadapi dan solusi yang diberikan. Penelitian menggunakan pendekatan kualitatif, pengumpulan data dengan triangulasi sumber dan teknik. Analisis data menerapkan model alir melalui pengumpulan data, reduksi data, penyajian dan penarikan kesimpulan. Hasil penelitian menunjukkan bahwa untuk menerapkan nilai-nilai Bhineka Tunggal Ika pada siswa dapat dilakukan dengan cara membiasakan siswa untuk membayar pajak, memiliki sikap toleransi dan tidak membeda-bedakan antar umat beragama. Hambatan yang dialami yaitu berasal dari siswa yang kurang paham pada nilai-nilai Bhineka Tunggal Ika, selain itu hambatan juga berasal dari kurangnya kesadaran guru, staff/karyawan dalam menerapkan nilai-nilai Bhineka Tunggal Ika pada siswa di SMP Negeri 1 Surakarta. Solusi yang diberikan pihak sekolah selalu berupaya menambah pemahaman mengenai nialai-nilai Bhineka Tunggal Ika pada siswa agar pelaksanaan proses pembelajaran dapat berjalan dengan lancar, dan proses implementasi nilai- nilai Bhineka Tunggal Ika dapat tercapai, solusi selanjutnya yaitu membiasakan siswa melakukan indikator-indokator nilai-nilai Bhineka Tunggal Ika. Pihak sekolah dan guru berkoordinasi dengan staff/karyawan agar menerapkan nilai-nilai Bhineka Tunggal Ika pada siswa agar mereka terbiasa dengan pemahaman nilai-nilai tersebut, sehingga proses implementasi nilai-nilai Bhineka Tunggal Ika kepada siswa dapat tercapai secara maksimal.
\end{abstract}

Kata kunci: implementasi, nilai-nilai, Bhineka Tunggal Ika. 


\section{IMPLEMENTATION OF IKA SINGLE BHINEKA VALUES IN CLASS VII STUDENTS OF SMP Negeri 1 SURAKARTA IN 2016/2017 ACADEMIC YEAR}

Article

Author

Umi Setyaningsih ${ }^{1}$

S2 Students Civics Study Program

Postgraduate Program UNS Surakarta

Yulianto Bambang Setyadi ${ }^{2}$

Doctoral students in Educational Evaluation and Research Study Program

Postgraduate Program UNY Yogyakarta

\section{ABSTRACT}

This study aims to describe the implementation process of Bhineka Tunggal Ika value on students Grade VII in SMP Negeri 1 Surakarta in Academic Year 2016/2017, various problems encountered and solutions are provided. The researcher used qualitative approach, collecting data with source triangulation and technique. The researcher analyzed the data by using alir models through data collection, data reduction, presentation and conclusion. The results showed that applying Bhineka Tunggal Ika values to students can be done by familiarizing students to pay taxes, tried to build their tolerance and do not discriminate between religious people. The problems which happened in the students besides they are not familiar with the values of Bhineka Tunggal Ika, but also the lack of awareness of teachers, staff / employees in applying the values of Bhineka Tunggal Ika to students in SMP Negeri 1 Surakarta. The solution provided by the school is always trying to increase the understanding of the values of Bhineka

Tunggal Ika to students so that the learning process can run well, and the implementation process of Bhineka Tunggal Ika's values can be achieved, the next solution is to familiarize the students to perform the indicators of value-Value of Bhineka Tunggal Ika. The school and teachers coordinate each other with the staff / employees to apply the values of Bhineka Tunggal Ika to the students. So that they are familiar to understand of these values, so that the implementation process of Bhineka Tunggal Ika's values to the students can be achieved maximally.

Keywords: implementation, values, Unity in Diversity. 


\section{Pendahuluan}

Pendidikan sangat penting dan menduduki posisi sentral dalam pembangunan karena berorientasi pada peningkatan kualitas sumber daya manusia. Menurut Ihsan (2010: 1-2), pendidikan sebagai usaha manusia untuk menumbuhkan dan mengembangkan potensi-potensi pembawaan baik jasmani maupun rohani sesuai dengan nilai-nilai yang ada di dalam masyarakat dan kebudayaan. Pendidikan merupakan suatu proses transformasi nilai-nilai generasi yang lain. Undang-Undang Nomor 20 Tahun 2003 tentang Sistem Pendidikan Nasional Bab II Pasal 3 menyatakan bahwa:

Pendidikan nasional berfungsi mengembangkan kemampuan dan membentuk watak serta peradaban bangsa yang bermartabat dalam rangka mencerdaskan kehidupan bangsa, bertujuan untuk berkembangnya potensi peserta didik agar manusia yang beriman dan bertakwa kepada Tuhan Yang Maha Esa, berahklak mulia, sehat, berilmu, cakap, kreatif, mandiri, dan menjadi warga negara yang demokratis serta bertanggung jawab.

Multikultural berasal dari kata multi yang berarti beragam dan kultur memiliki arti budaya. Menurut Mulyana (2011: 183), multikulturalisme adalah masalah perbedaan identitas sebagai produk adat-istiadat dan kebiasaan, struktur sosial pada umumnya. Menurut Nasikun sebagaimana dikutip oleh Rustanto (2015: 40),

Masyarakat multikultural adalah suatu masyarakatbersifat majemuk sejauh masyarakat tersebut secara struktur memiliki sub-sub kebudayaan yang bersifat diverse yang ditandai oleh kurang berkembangnya sistem nilai yang disepakati oleh seluruh anggota masyarakat dan juga sistem nilai dari satu-kesatuan sosial, serta seringnya muncul koonflikkonflik sosial.

Bangsa Indonesia terdiri dari berbagai kelompok etnis, budaya, agama, bahasa, adat istiadat, dan lainlain sehingga dapat disebut sebagai masyarakat majemuk atau multikultural. Menurut J. S. Furnivall sebagaimana dikutip oleh Rustanto (2015: 34) masyarakat majemuk adalah suatu masyarakat yang terdiri atas dua atau lebih elemen yang hidup sendirisendiri tanpa ada pembaharuan satu sama lain di dalam suatu keadaan politik. Bhineka Tunggal Ika memiliki konsep sebagai landasan multikulturalisme. Multikulturalisme secara sederhana dapat dikatakan pengakuan atas pluralisme budaya. Pluralisme budaya bukanlah suatu yang given tetapi merupakan suatu proses internalisasi nilai-nilai didalam suatu komunitas (Tilaar, 2004: 179). Bhineka Tunggal Ika bukanlah sekedar semboyan saja tetapi juga sebagai lambang Negara. Menurut Saputra dan Nugroho (2013: 119) prinsipnya Bhineka Tunggal Ika mengandung makna meliputiMendorong makin kukuhnya persatuan Indonesia, mendorong timbulnya kesadaran tentang pentingnya pergaulan demi kukuhnya persatuan dan kesatuan, tidak saling menghina, mencemooh, atau saling menjelekkan di antara sesama bangsa indonesia, saling menghormati dan saling mencintai antar sesama, meningkatkan identitas 
dan kebanggaan sebagai bangsa indonesia, meningkatkan nilai kegotongroyongan dan solidaritas.

Prinsip Bhineka Tunggal Ika mendukung nilai-nilai seperti: inklusif, terbuka, damai dan kebersamaan, kesetaraan, toleransi, musyawarah disertai dengan penghargaan terhadap pihak lain yang berbeda. Sejalan dengan prinsip, berikut ini adalah langkah-langkah untuk mengimplementasikan konsep Bhineka Tunggal Ika sebagai landasan multikulturalisme untuk mewujudkan persatuan bangsa meliputi perilaku inklusif, Sikap rukun dan damai, Musyawarah untuk mencapai mufakat, Sikap kasih sayang dan rela berkorban

Bila setiap warga negara memahami makna Bhineka Tunggal Ika, meyakini akan ketepatannya bagi landasan kehidupan berbangsa dan bernegara yang multikulturalisme, serta mau dan mampu mengimplementasikan secara tepat dan benar, maka negara Indonesia akan tetap kokoh dan bersatu selamanya. Pepatah yang mengatakan "Bersatu kita teguh bercerai kita runtuh".

Tujuan penelitian ini meliputi mendiskripsikan proses, hambatan, solusi implementasi nilai-nilai Bhineka Tunggal Ika pada siswa kelas VII di SMP Negeri1 Surakarta.

\section{Kajian Teori}

Kata implementasi biasanya selalu berhubungan dengan suatu kebijakan. Implementasi merupakan suatu proses penerapan ide, konsep, atau inovasi dalam suatu tindakan praktis sehingga memberi dampak, baik berupa perubahan pengetahuan, keterampilan maupun nilai, dan sikap. Menurut Harsono (2002: 67), implementasi adalah suatu proses untuk melaksanakan kebijakan menjadi tindakan kebijakan dari politik menjadi administrasi. Menurut Usman (2002: 70), implementasi bukan sekedar aktivitas, tetapi suatu kegiatan yang terncana dan untuk mencapai tujuan kegiatan. Berdasarkan pendapat tersebut, dapat disimpulkan bahwa implementasi adalah bukan sekedar aktivitas, tetapi suatu kegiatan yang terencana dan dilakukan secara sungguh-sungguh berdasarkan acuan norma tertentu untuk mencapai tujuan kegiatan.

Pengertian Nilai. Nilai memuat elemen pertimbangan yang membawa ideide seorang individu mengenai hal-hal yang benar, baik, ataupun yang diinginkan dan nilai-nilai itu bersumber dari agama maupun dari tradisi humanistik. Menurut Syarbaini (2012: 43-44), nilai adalah sesuatu yang berharga, berguna, indah, memperkaya batin, dan menyadarkan manusia akan harkat dan martabatnya. Menurut J.J Kuperman sebagaimana dikutip Mulyana (2011: 9), nilai adalah patokan normatif yang mempengaruhi manusia dalam menentukan pilihannya di antara cara-cara tindakan alternatif. Menurut Gordon Allport sebagaimana dikutip oleh Mulyana (2011: 9), nilai adalah keyakinan yang membuat seseorang bertindak atas dasar pilihannya. Berdasarkan beberapa pendapat tersebut, dapat disimpulkan bahwa nilai adalah patokan normatif yang mempengaruhi keyakinan manusia yang menentukan pilihannya dengan cara melakukan tindakan normatif dan atas dasar pilihannya.

Macam-macam Nilai. Menurut Syarbaini (2012:48-49), nilai dapat dikelompokkan menjadi tiga macam sebagaimana uraian berikut:

1) Nilai Dasar yaitu tidak dapat diamati melalui panca indera manusia, tetapi dalam kenyataannya nilai berhubungan dengan tingkah laku atau berbagai aspekk kehidupan manusia.

2) Nilai Instrumental yaitu nilai yang menjadi pedoman pelaksanaan dari nilai dasar. 
3) Nilai Praksis merupakan pelaksanaan secara nyata dari nilai-nilai dasar dan nilai-nilai instrumental.

Menurut Notonegoro sebagaimana dikutip oleh Syarbaini (2012: 44), membagi nilai dalam tiga kategori, yaitu sebagai berikut:

1) Nilai material, yaitu segala sesuatu yang berguna bagi unsur manusia.

2) Nilai vital, yaitu segala sesuatu yang berguna bagi manusia untuk melakukan aktivitas.

3) Nilai kerohanian, yaitu segala sesuatu yang berguna bagi rohani manusia.

Pengertian Bhineka Tunggal Ika. Menurut Toyibi dan Djahiri (1997: 77), "Bhineka Tunggal Ika adalah keberagaman dalam kesatuan". Kesatuan merupakan sebuah gambaran ideal. Dikatakan ideal karena kesatuan merupakan suatu harapan atau cita-cita untuk mengangkat atau menempatkan unsur perbedaan yang terkandung dalam keanekaragaman bangsa Indonesia ke dalam suatu wadah, yakni Negara Kesatuan Republik Indonesia. Kesatuan adalah upaya untuk menciptakan wadah yang mampu menyatukan perbedaan atau keaneka-ragaman. Berdasarkan uraian di atas dapat dikatakan bahwa Bhineka Tunggal Ika merupakan pernyataan jiwa dan semangat bangsa Indonesia yang mengakui realitas bangsa yang majemuk, namun tetap menjunjung tinggi kesatuan. Bhineka Tunggal Ika adalah semboyan bangsa yang tercantum dan menjadi bagian dari lambang negara Indonesia, yaitu Garuda Pancasila. Diuraikan kata per kata, Bhineka berarti berbeda, Tunggal berarti Satu, dan Ika berarti Itu. Jadi, dapat disimpulkan bahwa walaupun berbeda-beda, tapi pada hakekatnya satu. Kata lain, seluruh perbedaan yang ada di Indonesia menuju tujuan yang satu atau sama, yaitu bangsa dan Negara Indonesia. Semboyan bangsa, artinya Bhineka Tunggal Ika adalah pembentuk karakter dan jati diri bangsa.

Bhineka Tunggal Ika sebagai pembentuk karakter dan jati diri bangsa ini tak lepas dari campur tangan para pendiri bangsa yang mengerti benar bahwa Indonesia yang pluralistik memiliki kebutuhan akan sebuah unsur pengikat dan jati diri bersama. Bhineka Tunggal Ika pada dasarnya merupakan gambaran dari kesatuan geopolitik dan geobudaya di Indonesia, yang artinya terdapat keberagaman dalam agama, ide, ideologis, suku bangsa dan bahasa. Bhineka Tunggal Ika adalah cerminan keseimbangan antara unsur perbedaan yang menjadi ciri keanekaan dengan unsur kesamaan yang menjadi ciri kesatuan. Keseimbangan itu sendiri merupakan konsep filsafati yang selalu terletak pada ketegangan di antara dua titik ekstrim, yaitu keanekaan mutlak disatu pihak dan kesatuan mutlak di pihak lain. Setiap kali segi keanekaan yang menonjolkan perbedaan itu memuncak akan membawa kemungkinan munculnya konflik, maka kesatuanlah yang akan meredakan atas dasar kesadaran nasional.

Sejarah Konsep Bhineka Tunggal Ika. Awalnya, semboyan yang dijadikan semboyan resmi Negara Indonesia sangat panjang, yaitu Bhineka Tunggal Ika Tan Hana Dharmma Mangrwa. Semboyan Bhineka Tunggal Ika dikenal untuk pertama kalinya pada masa Majapahit era kepemimpinan Wisnuwardhana. Perumusan semboyan Bhineka Tunggal Ika ini dilakukan oleh Mpu Tantular dalam kitab Sutasoma. Hal itu dilakukan sehubungan usaha bina Negara kerajaan Majapahit saat itu. Semboyan Negara Indonesia ini telah memberikan nilai-nilai inspiratif terhadap sistem pemerintahan pada masa kemerdekaan. Bhineka Tunggal Ika pun telah menumbuhkan semangat persatuan dan kesatuan Negara Kesatuan Republik Indonesia. Kitab Sutasoma, definisi Bhineka Tunggal Ika lebih ditekankan pada perbedaan dalam hal kepercayaan dan keanekaragaman agama yang ada di kalangan masyarakat Majapahit.Namun, sebagai semboyan Negara Kesatuan Republik Indonesia, konsep Bhineka Tungggal Ika bukan hanya perbedaan agama dan kepercayaan menjadi fokus, tapi pengertiannya lebih luas. 
Bhineka Tunggal Ika sebagai semboyan Negara memiliki cakupan lebih luas, seperti perbedaan suku, bangsa, budaya (adat istiadat), beda pulau, dan tentunya agama dan kepercayaan yang menuju persatuan dan kesatuan Nusantara. Semboyan Bhineka Tunggal Ika Tan Hana Darma Mangrwa adalah ungkapan yang memaknai kebenaran aneka unsur kepercayaan pada Majapahit. Tidak hanya Siwa dan Budha, tapi juga seajumlah aliran (sekte) yang sejak awal telah dikenal lebih duku sebagian besar anggota masyarakat Majapahit yang memiliki sifat majemuk. Sehubungan dengan semboyan Bhineka Tunggal Ika, cikal bakal dari Singasari, yakni pada masa Wisnuwardhana sang dhinarmeng ring Jajaghu (candi Jago), semboyan tersebut dan Candi Jago disempurnakan pada masa Kerajaan Majapahit.

Mpu Tantular yang hidup pada abad ke-14 di Majapahit adalah seorang pujangga ternama Sastra Jawa. Ia hidup pada pemerintahan raja Rajasanegara. Ia masih saudara sang raja yaitu keponakannya (Bratratmaja dalam bahasa Kawi atau bahasa Sansekerta) dan menantu adik wanita sang raja. Nama "Tantular" terdiri dari dua kata, yaitu tan (tidak) dan tular (terpengaruh). Artinya ia orangnya "teguh". Kata "mpu" merupakan gelar yang artinya adalah seorang yang pandai atau ahli. Tantular adalah seorang penganut agama Budha, namun ia terbuka terhadap agama lainnya, terutama agama Hindu-Siwa. Bisa terlihat pada dua kakawin atau syairnya yang ternama yaitu kakawin Arjunawijaya dan terutama kakawin Sutasoma. Salah satu bait dari kakawin Sutasoma ini diambil menjadi motto atau semboyan Republik Indonesia yaitu "Bhineka tunggal Ika" atau berbedabeda namun satu jua. Perumusan Bhineka Tunggal Ika oleh Mpu Tantular pada dasarnya pernyataan daya kreatif dalam upaya mengatasi keanekaragaman kepercayaan dan keagamaan.

Makna dan Konsep Bhineka Tunggal Ika. Jika dianalisis, semboyan
Bhineka Tunggal Ika yang berasal dari bahasa Sansekerta itu terdiri dari kata Bhineka, Tunggal, dan Ika. Kata Bhinneka berasal dari kata Bhinna dan Ika. Bhina artinya berbeda-beda dan Ika artinya itu. Jadi, kata Bhineka berarti yang berbedabeda itu. Analisa lain menunjukkan bahwa kata Bhineka terdiri dari unsur kata "bhinn-a-eka". Unsur "a" artinya tidak, dan "eka" artinya satu. Kata Bhineka juga dapat berarti "yang tidak satu". Kata Tunggal artinya satu, dan Ika artinya itu. Berdasarkan analisis tersebut dapat disimpulkan bahwa semboyan "Bhineka Tunggal Ika" berarti "yang berbeda-beda itu dalam yang satu itu" atau "beranekaragam namun satu jua". Kebhinekaan atau yang berbeda-beda itu menunjuk pada realitas objektif masyarakat Indonesia yang memiliki keanekaragaman yang tinggi. Keanekaragaman masyarakat Indonesia dapat ditemukan dalam berbagai bidang kehidupan. Keanekaragaman di bidang politik, bidang ekonomi, bidang sosial, juga dapat dilihat dari segi geografis, budaya, agama, etnis, dan sebagainya.

Adanya keanekaragaman dalam berbagai bidang tersebut menyebabkan Indonesia dijuluki sebagai masyarakat yang multi etnik, multi agama (multi religi), multi budaya (multikultural), dan sebagainya. Makna kesatuan (tunggal ika) dalam Bhineka Tunggal Ika merupakan cerminan rasionalitas yang lebih menekankan kesamaan daripada perbedaan. Bhineka Tunggal Ika merumuskan dengan tegas adanya harmoni antara kebhinekaan dan ketunggalikaan, antara keanekaan dan keekaan, antara keragaman dan kesatuan, antara hal banyak dan hal satu, atau antara pluralisme dan monisme. Demikian pula sebaliknya, manakala segi kesatuan yang menonjolkan kesamaan itu tampil secara berlebihan, maka keanekaan selalu mengingatkan bahwa perbedaan adalah kodrat sekaligus berkah yang tak terelakkan. Semboyan Bhineka Tunggal Ika merupakan pernyataan yang mengakui realitas bangsa 
Indonesia yang majemuk (berbhineka), namun selalu mencita-citakan terwujudnya kesatuan (ketunggal-ikaan). Indonesia yang ber-Bhineka Tunggal Ika berarti Indonesia selain mengakui adanya keberagaman atau perbedaan juga mengakui adanya kesatuan dan tetap berkeinginan untuk menjadi satu bangsa, yaitu bangsa Indonesia. Kebhinnekaan merupakan ciri dasar bangsa Indonesia sejak Republik ini dibentuk, kemudian diproklamasikan oleh para pendiri negara (the founding fathers) pada paruh kedua abad silam hingga kini. Sebagai suatu realitas objektif, maka kebhinekaan telah menjadi identitas bangsa Indonesia. Baik keanekara-gaman maupun kesatuan Indonesia adalah kenyataan sekaligus persoalan. Kebhinekaan Indonesia sepintas lalu memang jauh lebih menonjol daripada kesatuannya. Membeda-bedakan sesuatu yang berbeda hanya akan menimbulkan bahaya disintegrasi. Perbedaan dalam kebhinekaan perlu disinergikan atau dikelola dengan cara mendayagunakan aneka perbedaan menjadi modal sosial untuk membangun kebersamaan. Diperlukan adanya kesadaran, kemauan, dan kemampuan untuk melihat kesamaan pada sesuatu yang berbeda.

Prinsip-prinsip yang terkandung dalam Bhineka Tunggal Ika. Menurut Winarno (2013: 11), prinsip Bhineka Tunggal Ika adalah:

Kesediaan warga bangsa untuk bersatu dalam perbedaan. Yang disebut bersatu dalam perbedaan adalah kesediaan warga bangsa untuk setia pada lembaga yang disebut negara dan pemerintahnya, tanpa menghilangkan keterikatannya pada suku bangsa, adat, ras, dan agamanya.

Mengimplementasikan Bhinneka Tunggal Ika dalam kehidupan berbangsa dan bernegara dipandang perlu untuk memahami secara mendalam prinsip-prinsip yang terkandung dalam Bhinneka Tunggal
Ika. Prinsip-prinsip tersebut menurut Ubaidillah (2006: 13) adalah sebagai berikut: Faham Bhineka Tunggal Ika, yang oleh Ir Sujamto disebut sebagai faham Tantularisme, bukan faham sinkretisme, yang mencoba untuk mengembangkan konsep baru dari unsur asli dengan unsur yang datang dari luar. Bhineka Tunggal Ika tidak bersifat sektarian dan eksklusif, Bhineka Tunggal Ika bersifat inklusif. Golongan mayoritas dalam hidup berbangsa dan bernegara tidak memaksakan kehendaknya pada golongan minoritas. Bhineka Tunggal Ika dilandasi oleh sikap saling percaya mempercayai, saling hormat menghormati, saling cinta mencintai dan rukun. Bhineka Tunggal Ika bersifat konvergen tidak divergen, yang bermakna perbedaan yang terjadi dalam keanekaragaman tidak untuk dibesar-besarkan, tetapi dicari titik temu, dalam bentuk kesepakatan bersama. Hal ini akan terwujud apabila dilandasi oleh sikap toleran, non sektarian, inklusif, akomodatif, dan rukun.

Indikator yang berkaitan dengan Bhineka Tunggal Ika. Indikator tersebut diambil berdasarkan ciri-ciri Bhineka Tunggal Ika yaitu sebagai berikut: Adanya persamaan dan kewajiban bagi setiap warga negara, Tidak ada rasialisme, Tumbuh dan berkembang, Tidak adanya sikap deskriminatif, Adanya sikap kerukunan dan kedaerahan, Berbeda agama tapi tetap satu, dan Tidak membedabedakan

Segala peraturan perundangundangan khususnya peraturan daerah harus mampu mengakomodasi masyarakat yang pluralistik dan multikutural, dengan tetap berpegang teguh pada dasar negara Pancasila dan 
UUD NRI Tahun 1945. Suatu peraturan perundang-undangan, utamanya peraturan daerah yang memberi peluang terjadinya perpecahan bangsa, atau yang sematamata untuk mengakomodasi kepentingan unsur bangsa harus dihindari. Penerapkan nilai-nilai tersebut secara konsisten akan terwujud masyarakat yang damai, aman, tertib, teratur, sehingga kesejahteraan dan keadilan.

Implementasi atau penerapan nilainilai Bhineka Tunggal Ika harus tercermin pada pola pikir, pola sikap, dan pola tindak yang senantiasa mendahulukan kepentingan bangsa serta NKRI dari pada kepentingan pribadi atau kelompok. Darji (1996: 12) mengatakan bahwa "implementasi nilai Bhineka Tunggal Ika harus terealisasi dalam politik, sosial budaya, dan seluruh aspek kehidupan berbangsa dalam penyelenggaraan negara yang sehat dan dinamis". Pemahaman nilai-nilai Bhineka Tunggal Ika harus dijadikan arahan, pedoman, acuan, dan tuntunan bagi setiap individu dalam bertindak serta memelihara tuntutan bangsa yang terintegrasi secara nasional demi keutuhan NKRI yeng dikenal dengan masyarakat multikultural. Kesatuan adalah upaya untuk menciptakan wadah yang mampu menyatukan perbedaan atau keanekaragaman. Implementasi nilai-nilai Bhineka Tunggal Ika dirasa sangat penting di terapkan pada siswa, guru dan masyarakat karena mereka hidup bermasyarakat. Adanya keterkaitan antara implementasi nilai-nilai Bhineka Tunggal Ika dengan pembelajaran Pendidikan Pancasila dan Kewarganegaraan merupakan variabel yang saling terhubung dalam suatu sistem pembelajaran. Bhineka Tunggal Ika memiliki konsep sebagai landasan multikulturalisme yang perlu diketahui dan dipahami oleh siswa dan guru dalam proses pembelajaran bahkan dalam kehidupan bermasyarakat. Nilainilai Bhineka Tunggal Ika dapat meningkatkan pemahaman mengenai persatuan dan kesatuan yang ada di Indonesia dan dalam kehidupan bermasyarakat.

\section{Metode}

Tempat penelitian adalah SMP Negeri 1 Surakarta. Tahap dalam pelaksanaan kegiatan ini dimulai dari tahap persiapan dengan penulisan laporan penelitian. Secara keseluruhan semua kegiatan dilakukan selama kurang lebih empat bulan, yaitu sejak April sampai Juli 2017. Menurut Sugiyono (2010: 4-7), berdasarkan jenis-jenis penelitian di atas, maka dapat dikemukakan bahwa yang termasuk metode kuantitatif adalah metode penelitian eksperimen dan survey, sedangkan yang termasuk dalam metode penelitian kualitatif yaitu metode naturalistik. Penelitian untuk basic research pada umumnya menggunakan eksperimen dan kualitatif, applied research menggunakan eksperimen dan survey, dan $R \& D$ dapat menggunakan survey, kualitatif dan eksperimen. Jenis penelitian ini menggunakan metode jenis penelitian kualitatif naturalistik. Penelitian ini tidak memberikan perlakuan, hasil penelitian bukan berdasarkan pandangan dari peneliti sendiri melainkan dari pandangan sumber data atau informan.

Penelitian ini menggunakan teknik pengumpulan data meliputi observasi, wawancara, dan dokumentasi. Teknik analisis data yang digunakan dalam penelitian ini yaitu teknik analisis data kualitatif. Menurut Miles dan Huberman (1992:15-19), proses analisis data dimulai dengan mengumpulkan data dilokasi penelitian dengan melakukan observasi, wawancara, dan dokumentasi dengan menentukan strategi pengumpulan data yang dipandang tepat untuk menentukan fokus serta pendalaman data pada proses pengumpulan data berikutnya.

\section{Hasil Penelitian Dan Pembahasan}

\section{Hasil Penelitian}


Proses implementasi nilai-nilai Bhineka Tunggal Ika di SMP Negeri 1 Surakarta ini dilakukan dengan menggunakan pola pembiasaan oleh pihak sekolah kepada siswa dengan berbagai cara. Peneliti dalam mencari data menggunakan beberapa indikator untuk melihat ke efektifan pola pembiasaan sebagi cara untuk penerapan nilai-nilai Bhineka Tunggal Ika kepada siswa di SMP Negeri 1 Surakarta. Uraian indikator yang digunakan untuk penerapan nilai-nilai Bhineka Tunggal Ika di SMP Negeri 1 Surakarta sebagai berikut.

a. Indikator yang digunakan untuk penerapan nilai-nilai Bhineka Tunggal Ika.

1) Adanya persamaan dan kewajiban bagi setiap warga negara. Indikator yang pertama, yaitu adanya persamaan dan kewajiban bagi setiap warga negara. Proses penerapan nilai-nilai Bhineka Tunggal Ika di SMP Negeri 1 Surakarta, upaya yang dilakukan oleh guru dan pihak sekolah, yaitu dengan membiasakan siswa untuk wajib membayar pajak. Pola pembiasaan yang dilakukan oleh pihak sekolah dalam mengajak siswa agar senantiasa untuk membayar pajak adalah dengan cara memberikan sosialisasi kepada siswa bahwa membayar pajak merupakan suatu kewajiban sebagai warga negara dan dengan begitu adanya persamaan antar warga negaranya. Guru dan pihak sekolah juga selalu memberi contoh pada siswa untuk selalu membayar pajak, misalnya membayar pajak motor, pajak tanah dan bangunan, pajak pembelian barang-barang, dan lain-lainnya.

Pola pembiasaan yang diberikan pada siswa agar dapat memiliki persamaan dan kewajiban sebagai warga negara degan membayar pajak, tidak hanya membayar pajak maka siswa di SMP Negeri 1 Surakarta diwajibkan untuk mencari ilmu yang seluas-luasnya dan bersama-sama meraih prestasi setinggi mungkin. Hal tersebut dibenarkan oleh Ibu Iwan
Purniwiyati, S.Pd selaku guru PPKn SMP Negeri 1 Surakarta. Hasil wawancara dengan Ibu Iwan Purniwiyati, S.Pd pada hari Jumat, 19 Mei 2017, terungkap bahwa:

Pihak sekolah melakukan pola pembiasan untuk membuat siswa bangga terhadap negaranya yaitu dengan mengajarkan dan memberi contoh kepada siswa agar selalu membayar pajak karena membayar pajak adalah kewajiban sebagai warga negara dan selalu membiasakan siswa untuk belajar mencari ilmu yang seluas-luasnya dan bersaing dalam memperoleh prestasi yang setinggi-tingginya karna ini merupakan kewajiban sebagai siswa. Sejauh ini kami pihak sekolah menghimbau kepada siswa agar tetap membayar pajak dan selalu belajar mencari ilmu yang seluas-luasnya untuk bekal dimasa depannya, dengan begitu siswa yang rajin mencari ilmu akan mendapatkan prestasi yang memuaskan yang akan membuatnya, orang tua dan sekolah bangga akan prestasi yang diraihnya.

Hasil wawancara dengan Ibu Iwan Purniwiyati, S.Pd mengenai menanamkan rasa bangga terhadap kewajibannya sebagai warga negara dan sebagai siswa sebagai upaya untuk menanamkan kewajiban sebagai warga negara juga disampaikan oleh Ibu Susniwati Rahayu, S.Pd pada hari Jumat, 19 Mei 2017, terungkap bahwa:

Terkait dengan persamaan dan kewajiban sebagai warga negara kepada siswa, kami selaku guru PPKn yang ada di SMP Negeri 1 Surakarta membiasakan siswa untuk menanamkan kewajiban sebagai warga negara dan persamaan antar warga negara. Hal ini kami lakukan untuk menjaga agar rasa memiliki kewajiban dan persamaan yang akan menimbulkan rasa bangga siswa dengan melakukan hal tersebut 
terhadap negaranya semakin besar, sehingga kewajiban dan persamaan warga negara tertanam dalam diri setiap siswa di SMP Negeri 1 Surakarta.

Hasil wawancara dengan Ibu Iwan Purniwiyati, S.Pd dan Ibu Susniwati Rahayu, S.Pd mengenai upaya pihak sekolah dalam menanamkan persamaan dan kewajiban sebagai warga negara pada siswa di SMP Negeri 1 Surakarta juga disampaikan oleh Hasna Putri, salah satu siswa di SMP Negeri 1 Surakarta. Berikut hasil wawancara dengan Hasna Putri pada Sabtu, 20 Mei 2017 terungkap bahwa:

Saya sebagai siswa SMP Negeri 1 Surakarta sering mendapatkan pengarahan dan ilmu untuk selalu melakukan kewajiban sebagai warga negara untuk terwujudnya persaman antar warga. Berawal dari pengarahan dan contoh yang dilakukan guru, saya jadi termotivasi untuk membayar pajak dan mencari ilmu seluas-luasnya untuk meraih prestasi yang diinginkan yang pada ahkirnya akan membuat bangga diri saya sendiri dan orang-orang terdekat saya dan sekolah. Saya haru bangga tergahap negara ini karena dengan kewajiban membayar pajak dapat membuatwarga negara memiliki persamaan yang akan menimbulkan persatuan tanpa adanya perbedaan yang ditimbulkan akibat kewajiaban sebagai warga negara tersebut.

Pelaksanaan peningkatan melalui proses pembelajaran pada siswa di SMP Negeri 1 Surakarta. Peningkatan melalui proses pembelajaran dilakukan dengan cara meningkatkan model dan sarana prasaran yang mendukung untuk tumbuh dan berkembangnya siswa. Hal ini bertujuan untuk meningkatkan tumbuh dan berkembangnya kemapuan siswa dalam akademik dan non akademik. Peningkatan tumbuh dan berkembang di dalam non akademik dengan cara mengikuti kegiatan ekstrakulikuler yang ada di sekolah sesuai dengan minat dan kempuan yang dimiliki oleh setiap siswa, dengan begitu siswa dapat tumbuh dan berkembang tidak hanya dalam konteks akademik namun juga nonakademik. Hal tersebut dibenarkan oleh Bapak Supriyanto, S.Pd selaku wakil kepala sekolah di bidang kurikulum di SMP Negeri 1 Surakarta. Hasil wawancara dengan BapakSupriyanto, S.Pd pada hari Jum'at, 26 Mei 2017, terungkap bahwa:

Pihak sekolah selalu menekankan pada guru untuk selalu meningkatkan proses pembelajaran yang berupa peningkatan model dan sarana prasarana yang mendukung tumbuh dan berkembangnya siswa. SMP Negeri 1 Surakarta menggunakan kurikulum K13 dengan begitu guru dan siswa dituntut sekreatif mungkin dalam proses pembelajran di dalam kelas. Cara tersebut kami lakukan untuk meningkatkan tumbuh dan berkembangnya siswa dalam proses pembelajaran.

Hasil wawancara dengan Bapak Supriyanto, S.Pd mengenai cara yang dilakukan untuk meningkatkan tumbuh dan berkembangnya siswa juga disampaikan oleh Bapak Sediyoko, S.Pd selaku wakil kepala sekolah di bidang kesiswaan di SMP Negeri 1 Surakarta. Hasil wawancara dengan Bapak Sediyoko, S.Pd pada hari Sabtu, 20 Mei 2016, terungkap bahwa:

Terkait dengan mengajarkan siswa untuk setia dan taat terhadap negara, kami selaku pihak sekolah membiasakan siswa agar mengikuti kegiatan di luar jam pelajaran misalnya mengikuti kegiatan ekstrakulikuler. Dengan pembiasaan tersebut siswa dapat tumbuh dan berkembang sesuai kemampuan minat di bidang non akademik. Selain menekankan pada guru untuk meningkatkan model pembelajaran yang dilakukan pihak sekolah juga menekankan pada siswa untuk mengikuti proses pembelajaran secara baik dan sesuai aturan yang 
sudah diterapkan oleh pihak sekolah. Hal ini kami lakukan untuk membiasakan siswa taat pada semua aturan, sehingga setelah berada di dalam masyarakat, menjalani kehidupan berbangsa dan bernegara yang sesungguhnya, maka siswa sudah terbiasa mentaati peraturan yang ada, sehingga melalui proses pembiasaan tersebut dapat menanamkan di dalam diri siswa untuk lebih meningkatkan prestasi dalam proses pembelajaran.

Pembiasaan yang dilakukan oleh pihak sekolah agar siswa di SMP Negeri 1 Surakarta terbiasa berbasa dengan baik yang menimbulkan kerukunan antar siswa, guru, dan staff/karyawan. Hal ini dillakukan untuk menanamkan nilai-nilai Bhineka Tunggal Ika pada siswa di SMP Negeri 1 Surakarta.

2) Berbeda agama tapi tetap satu. Berbeda agama tapi tetap satu di SMP Negeri 1 Surakarta telah menerapkan sikap tersebut. SMP Negeri 1 Surakarta terdapat berbagai macam agama antara lain, Islam, Kristen, Katholik, Protestan dan Budha bahkan ada yang beragama Hindu. Siswa di SMP Negeri 1 Surakarta didominasi agama Islam dengan begitu hubungan antar umat beragama sangat harmonis karena mereka telah paham adanya sikap toleransi antar umat beragama.

Berdasarkan beragam agama yang dianut oleh siswa SMP Negeri 1 Surakarta tersebut terciptalah persatuan. Proses pembelajaran pada saat pelajaran agama, siswa yang beragama non islam belajar di ruang ibadah sendiri-sendiri dengan guru yang ada di SMP Negeri 1 Surakarta untuk agama Budha dan Hindu pihak sekolah mendatangkan guru dari luar. Hal tersebut dibenarkan oleh Bapak Drs. Joko Slameto, M.Pd selaku kepala sekolah SMP Negeri 1 Surakarta. Hasil wawancara dengan Bapak Drs. Joko Slameto, M.Pd pada hari Jum'at, 19 Mei 2017 terkait dnegan perbedaan agama tapi tetap satu di SMP Negeri 1 Surakarta, terungkap bahwa:
Siswa-siswi di SMP Negeri 1 Surakarta selalu kami tekankan untuk saling menghormati antar umat beragama untuk menciptakan persatuan dan kerukunan. Pembiasaan ini tidak hanya ditekankan pada siswa tetapi juga ditekankan pada guru dan staff/ karyawan disini. Masalah guru pada saat pembelajaran agama di SMP Negeri 1 Surakarta ini kita datangkan guru agama yang dibutuhkan di sekolah ini, karena siswa membutuhkan guru untuk menambah keimanan mereka. Kegiatan yang berkaitan dengan keagamaan kita ada pendidikan karakter yaitu berupa pendalaman keagaman yang dilakukan setiap hari Sabtu. Setiap hari juga dibiasakan 15 menit sebelum pelajaran di mulai siswa diminta untuk yang beragama Islam membaca surat-surat pendek dan yang beragama non islam pindah keruang agama masing-masing untuk membaca alkitab dan lain-lain yang berkaitan degan agama mereka masing.masing.

Hasil wawancara dengan Bapak Drs. Joko Slameto, M.Pd mengenai berbeda gama tapi tetap satu juga disampaikan oleh Ibu Susniwati Rahayu, S.Pd selaku guru PPKn diSMP Negeri 1 Surakarta. Hasil wawancara dengan Ibu Susniwati Rahayu, S.Pd pada hari Jum'at, 19 Mei 2016, terungkap bahwa:

Terkait dengan perbedaan agama pada siswa di SMP Negeri 1 Surakarta ini terlihat dari siswa yang beragama Islam pada istirahat pertama melaksanakan sholat dhuha di mushola sekolah dan beragama non Islam ada yang di ruang agama dan ada juga yang berada di kantin sekolah. Kegiatan yang mencerminkan perbedaan agama tapi tetap satu melalui kegiatan pada saat Idul Adha siswa saling tolong menolong pada saat penyembelihan 
hewan kurban dan pada saat pembagian daging kurban juga diikuti oleh siswayang beragama non islam.

Hasil wawancara dengan Ibu Susniwati Rahayu, S.Pd selaku kepala sekolah serupa dengan yang diungkapkan oleh Bapak Drs. Joko Slameto, M.Pd mengenai berbeda agama tapi tetap satu di SMP Negeri 1 Surakarta juga disampaikan oleh Hasna Putri salah satu siswa yang beragama Islam. Berikut hasil wawancara dengan Hasna Putri pada hari Sabtu, 20 Mei 2017, terungkap bahwa:

Saya selaku siswa di SMP Negeri 1 Surakarta, dan juga anggota OSIS senantiasa berusaha untuk menghargai perbedaan yang ada di antara saya dan teman-teman terutama masalah agama. Kegiatan yang kaami lakukan dalam organisasi OSIS ini tidak memnadang perbedaan agama , kami sadar dengan adanya sikap toleransi antar umat beragama. Kita disini sangat paham dengan persatuan dengan begitu kami saling menghargai pada saat beribadah. Sejauh ini kami tidak memiliki masalah yang berkaitan dengan perbedaan agama di SMP Negeri 1 Surakarta ini.

Berdasarkan keterangan yang diperoleh dari berbagai narasumber di atas mengenai salah satu indikator nilai-nilai Bhineka Tunggal Ika, yaitu berbeda agama tapi tetap satu yang mencerminkan sikap persatuan antar umat beragama, didapatkan data bahwa pihak sekolah dan guru SMP Negeri 1 Surakarta sudah melakukan upaya membiasakan siswa agar memiliki sikap toleransi dan persatuan antar umat beragam, sehingga sikap tersebut dapat tertanam dalam diri siswa.

Upaya yang dilakukan oleh pihak sekolah tersebut dapat dilihat dari usaha nyata dilapangan, mulai dari nasehat yang diberikan untuk menambah keimanan dan mendorong siswa untuk selal melakukan hal yang positif. Hal ini dilakukan dengan tujuan untuk meningkatkan keimanan siswa tidak hanya dengan pendidika formal tetapi pendidikan religius juga perlu di tingkatkan. Berdasarkan data yang di paparkan oleh beberapa narasumber di atas, dapat dilihat secara nyata dalam gambar berikut.

Proses penerapan nilai-nilai Bhineka Tunggal Ika tidak menutup kemungkinan terdapat hambatanhambatan yang dihadapi baik berasal dari siswa maupun dari guru sebagai seorang pengajar dan pendidik. Hasil wawancara dengan Bapak Drs. Joko Slameto, M.Pd pada hari Jum'at, 19 Mei 2017 terkait dengan hambatanhambatan yang dialami siswa dalam proses penerapan nilai-nilai Bhineka Tunggal Ika pada siswa di SMP Negeri 1 Surakarta, terungkap bahwa:

Problematika atau hambatan yang kami alami dalam proses implementasi/ penerapan nilainilai Bhineka Tunggal Ika di SMP Negeri 1 Surakarta sampai saat ini, yaitu mulai dari kurangnya pemahaman siswa tentang penerapan nilai-nilai Bhineka Tunggal Ika bagi diri mereka sampai dengan susahnya mengajak siswa untuk diajak kerjasama, misalkan untuk meningkatkan pemahaman mengenai penerapan nilai-nilai Bhineka Tunggal Ika. Kendala pada saat proses implementasi nilai-nilai Bhineka Tunggal Ika ini tidak terlalu besar hanya saja siswa disini sering kali memanggil nama temannya dengan nama ayahnya, tetapi hal tersebut tidak menimbulkan permasalahan yang besar. Kenakalan pada usia belasan sering terjadi pada siswa tetapi siswa di SMP Negeri 1 Surakarta tidak sampai menimbulkan 
perselisihan bahkan perpecahan antar siswa.

Hasil wawancara dengan Bapak Drs. Joko Slameto, M.Pd mengenai hambatan yang dialami pihak sekolah dalam proses implementasi nilai-nilai Bhineka Tunggal Ika pada siswa di SMP Negeri 1 Surakarta juga disampaikan oleh Bapak Sediyoko, S.Pd selaku wakil kepala sekolah di bidang kesiswaan di SMP Negeri 1 Surakarta. Hasil wawancara dengan Bapak Sediyoko, S.Pd pada hari Sabtu, 20 Mei 2017, terungkap bahwa:

Hambatan yang kami alami untuk implementasi nilai-nilai Bhineka Tunggal Ika pada siswa, yaitu kurang kepekaan siswa terhadap pentingnya nilai-nilai Bhineka Tunggal Ika pada diri siswa. Siswa di SMP Negeri 1 Surakarta saya rasa sudah tahu jika perlu adanya nilai-nilai Bhineka Tunggal Ika pada diri mereka. Hambatan siswa mengenai implementasi nilai-nilai Bhineka tunggal Ika hanya saja beberapa siswa yang masih memanggil temannya dengan nama ayahnya, tetapi untuk sikap toleransi anatar siswa dan warga sekolah sudah terjalin sangat baik.

dalam menjalani kehidupan berbangsa dan bernegara di Indonesia.

Hambatan lainnya, yaitu
kurangnya kesadaran $\begin{array}{r}\text { guru, } \\ \text { dalam menerapkan }\end{array}$
staff/karyawan
nilai-nilai Bhineka Tunggal Ika pada
siswa, sulitnya membiasakan siswa
melakukan indikator-indikator nilai-
nilai Bhineka Tunggal Ika dengan lebih
baik lagi. Terkait dengan nilai-nilai
Bhineka Tunggal Ika, masih ada siswa
yang terkadang tidak mau
meningkatkan pemahamannnya
mengenai penerapan nilai-nilai

Bhineka Tunggal Ika. Beberapa hambatan tersebut membuat pihak sekolah khususnya guru kesulitan dalam penerapan nilai-nilai Bhineka Tunggal Ika pada siswa di SMP Negeri 1 Surakarta.

Melihat proses implementasi nilai-nilai Bhineka Tunggal Ika di SMP Negeri 1 Surakarta yang masih mengalami beberapa hambatan, maka pihak sekolah dengan cepat mencari solusi sebagai upaya untuk mengatasi hambatan yang terjadi, agar proses implementasi nilai-nilai Bhineka Tunggal Ika di SMP Negeri 1 Surakarta dapat berjalan sesuai dengan harapan.

Hasil wawancara dengan Bapak Drs. Joko Slameto, M.Pd pada hari Jum'at, 19 Mei 2017 terkait dengan solusi untuk mengatasi hambatan-hambatan yang dialami dalam proses implementasi nilai-nilai Bhineka Tunggal Ika pada siswa di SMP Negeri 1 Surakarta, terungkap bahwa:

Untuk mengatasi masalah atau hambatan dalam proses implementasi nilai-nilai Bhineka Tunggal Ika, kami pihak sekolah berserta guru dan seluruh warga sekolah berusaha untuk memberikan pemahaman kepada siswa mengenai implementasi nilai-nilai Bhineka Tunggal Ika, kami selalu memberikan contoh kepada siswa untuk menciptakan persatuan dan kesatuan antar siswa dan siswa yang masih bandel melakukan kesalahan akan dikenai hukuman yang sudah menjadi peraturan di SMP Negeri 1 Surakarta. Terkait dengan hal tersebut, saat ini pihak sekolah selalu memberi contoh yang baik agar lebih baik kedepannya untuk siswa, guru, dan staff/karyawan.

Hasil wawancara dengan Ibu Susniwati Rahayu, S.Pd selaku guru mata pelajaran PPKndi SMP Negeri 1 Surakarta mengenai solusi untuk mengatasi hamabatan yang dialami pihak sekolah dalam proses implementasi nilai-nilai Bhineka Tunggal Ika pada siswa di SMP Negeri 1 Surakarta. Hasil wawancara dengan Ibu Susniwati Rahayu, 
S.Pd pada hari Jum'at, 19 Mei 2017, terungkap bahwa:

Saya selaku guru mata PPKn di SMP Negeri 1 Surakarta berusaha untuk selalu menyampaikan pentingnya kepada siswa agar memahami nilainilai Bhineka Tunggal Ika. Penerapan nilai-nilai Bhineka Tunggal Ika saya ajarkan kepada siswa sesuai dengan indikator-indikator yang ada. Terkadang dalam proses implementasi nilai-nilai Bhineka Tunggal Ika yang diterapkan pada siswa sedikit adanya paksaan dari guru mata pelajaran yang tidak hanya guru PPKn tetapi guru semua mata pelajaran, apabila semua sudah terbiasa otomatis penerapan nilai-nilai Bhineka Tunggal Ika dapat berjalan sesuai yang kita harapkan.

\section{Pembahasan}

Penanaman nilai-nilai Bhineka Tunggal Ika merupakan salah satu upaya yang dilakukan oleh pihak sekolah di SMP Negeri 1 Surakarta, hal ini karena dinilai hal tersebut sangat perlu dimiliki oleh remaja bangsa Indonesia, mengingat rasa persatuan dan kesatuan remaja sudah mulai luntur karena banyak adanya pertengkaran dan perpecahan yang dikarenakan beberapa faktor yang memicu hal tersebut.

Implementasi nilai-nilai Bhineka Tunggal Ika dan pola pembiasaan yang dilakukan oleh pihak sekolah seperti tidak membeda-bedakan antar umat beragama, tidak adanya rasialisme dalam lingkungan sekolah dan kehidupan sehari-hari. Hal ini didukung oleh hasil penelitain Dempsey, dkk (2016) menyatakan bahwa Bhineka Tunggal Ika adalah Penjelasan buku teks Bhineka Tunggal Ika juga terkait dengan (1) Filsafat, ideologi dan landasan negara, pancasila (2) Konstitusi republik Indonesia 1945

(3) Simbol pemersatu negara bangsa indonesia seperti Bendera nasional, lagu kebangsaan, dan bahasa (4) Sejarah perjuangan indonesia untuk indepence, dan (5) Sumpah pemuda. Penjelasan ini dimaksudkan untuk memperkuat gagasan bahwa Bhineka Tunggal Ika telah tertanam dalam kehidupan dan karakter negara-bangsa indonesia. Ini mewakili jiwa dan karakternya. Oleh karena itu, sekolah yang ingin menerapkan nilai-nilai Bhineka Tunggal Ika kepada siswa karena dirasa lebih tepat dan efektif.

Hambatan dalam proses implementasi nilai-nilai Bhineka Tunggal Ika pada siswa di SMP Negeri 1 Surakarta, yaittu terletak pada kurangnya pemahaman siswa tentang pentingnya nilai-nilai Bhineka Tunggal Ika dalam menjalani kehidupan berbangsa dan bernegara di Indonesia. Hambatan lainya, yaitu sulitnya membiasakan siswa melakukan indikator-indikator nilai-nilai Bhineka Tunggal Ika.Terkait nilai-nilai Bhineka Tunggal Ika, masih banyak siswa yang acuh terhadap nilai-nilai tersebut, terlihat dari hal sederhana yang setiap harinya dilakukan misalnya sikap toleransi pada kehidupan di lingkungan sekolah maupun di lingkungan masyarakat. Hambatan teknis dilapangan, yaitu kurangnya kesadaran guru, staff/karyawan dalam menerapkan nilai-nilai Bhineka Tunggal Ika pada siswa di SMP Negeri 1 Surakarta.

Solusi yang diberikan untuk mengatasi hambatan-hambatan yang terjadi dalam proses implementasi nilai-nilai Bhineka Tunggal Ika pada siswa di SMP Negeri 1 Surakarta, yaitu dengan cara menambah pemahaman mengenai nialai-nilai Bhineka Tunggal Ika pada siswa agar pelaksanaan proses pembelajaran dapat berjalan dengan lancar, dan proses implementasi nilai- 
nilai Bhineka Tunggal Ika dapat tercapai. Solusi lainnya, yaitu membiasakan siswa melakukan indikator-indokator nilai-nilai Bhineka Tunggal Ika. Pihak sekolah dan guru berkoordinasi dengan staff/karyawan agar menerapkan nilai-nilai Bhineka Tunggal Ika pada siswa agar mereka terbiasa dengan pemahaman nilai-nilai tersebut, sehingga proses implementasi nilai-nilai Bhineka Tunggal Ika kepada siswa dapat tercapai secara maksimal.

\section{Simpulan}

Hasil penelitian ini adalah proses implementasi nilai-nilai Bhineka Tunggal Ika di SMP Negeri 1 Surakarta, yaitu melalui proses pembelajaran baik materi maupun praktik di dalam kegiatan di luar proses pembelajaran. Pemahaman mengenai implementasi nilai-nilai Bhineka Tunggal Ika diketahui dapat ditanamkan melalui pola pembiasaan, seperti mengajak siswa untuk membayar pajak, tidak adanya rasialisme dalam kehidupan sehati-hari, dan lain-lain, sehingga siswa mampu memahami nilai-nilai tersebut dapat tertanam dan tumbuh dlaam diri siswa. Nilai-nilai Bhineka Tunggal Ika dapat ditanamkan melalui pembiasaan dengan mengajarkan siswa untuk selalu menggunakan bahasa kedaerahan tetapi tidak lepas penggunaan Bahasa Indonesia sebagai bahasa Nasional yang baik dan benar dalam lingkungan sekolah maupun di dalam lingkungan masyarakat. Hal ini bertujuan untuk meningkatkan pemahaman siswa terhadap nilai-nilai Bhineka Tunggal Ika, sehingga dapat tertanam dalam diri siswa.

Hambatan dalam proses implementasi nilai-nilai Bhineka Tunggal Ika pada siswa di SMP Negeri 1 Surakarta, yaittu terletak pada kurangnya pemahaman siswa tentang pentingnya nilai-nilai Bhineka Tunggal Ika dalam menjalani kehidupan berbangsa dan bernegara di Indonesia. Hambatan lainya, yaitu sulitnya membiasakan siswa melakukan indikator-indikator nilai-nilai Bhineka Tunggal Ika. Terkait nilai-nilai Bhineka Tunggal Ika, masih banyak siswa yang acuh terhadap nilai-nilai tersebut, terlihat dari hal sederhana yang setiap harinya dilakukan misalnya sikap toleransi pada kehidupan di lingkungan sekolah maupun di lingkungan masyarakat. Hambatan teknis dilapangan, yaitu kurangnya kesadaran guru, staff/karyawan dalam menerapkan nilai-nilai Bhineka Tunggal Ika pada siswa di SMP Negeri 1 Surakarta.

Solusi yang diberikan untuk mengatasi hambatan-hambatan yang terjadi dalam proses implementasi nilai-nilai Bhineka Tunggal Ika pada siswa di SMP Negeri 1 Surakarta, yaitu dengan cara menambah pemahaman mengenai nialai-nilai Bhineka Tunggal Ika pada siswa agar pelaksanaan proses pembelajaran dapat berjalan dengan lancar, dan proses implementasi nilainilai Bhineka Tunggal Ika dapat tercapai. Solusi lainnya, yaitu pihak sekolah dan guru berkoordinasi dengan staff/karyawan agar menerapkan nilai-nilai Bhineka Tunggal Ika pada siswa agar mereka terbiasa dengan pemahaman nilai-nilai tersebut, sehingga proses implementasi nilai-nilai Bhineka Tunggal Ika kepada siswa dapat tercapai secara maksimal. 


\section{Referensi}

Alexander, Dzhurinskiy. 2014. "School Policy in Russia and The Challenges of A Multicultural Society”. Social and Behavioral Sciences 186 ( 2015 ) 811 814. doi: 10.1016/j.sbspro.2015.04.181

Arikunto, Suharsimi. 2006. Prosedur Penelitian Suatu Pendekatan Praktik. Jakarta: Rineka Cipta.

Arikunto, Suharsimi. 2010. Prosedur Penelitian Suatu Pendekatan Praktik. Jakarta: Rineka Cipta.

Usman, Basyiruddin. 2002. Media Pendidikan. Jakarta: Ciputat Press.

Bungin, Burhan. 2008. Metodologi Penelitian Kualitatif. Jakarta: Kendana Pemuda Media Group.

Dempsey, Keith, Ching, Jerrica. 2016. "Cultural Competence Implication for Counselors in Training". Canada: Redfame Publishing

Harsono, Hanafi. 2002. Implementasi Kebijakan dan Politik. Bandung : Puataka Buana.

Ihsan, Fuad. 2020. Dasar-Dasar Kependidikan: Komponen MKD. Jakarta: PT RINEKA CIPTA

Herdiansyah, Haris. 2010. Metode Penelitian Kualitatif untuk Ilmu-ilmu Sosial. Jakarta: Salemba Humanika.

Janah, Hanif Nur. 2015. "Penanaman Nilai-Nilai Sila Kemanusiaan yang Adil Dan Beradab dalam Kegiatan Berorganisasi di Sekolah (Studi Kasus pada Anggota Kegiatan Ekstrakurikuler di Sma Negeri 1 Sine Kabupaten Ngawi Tahun 2015". Skripsi S-1. Surakarta: Fakultas Keguruan dan Ilmu Pendidikan Universitas Muhammadiyah Surakarta.

Kusuma, Wijaya dan Dedi Dwitagama. 2010. Mengenal Penelitian Tindakan Kelas. Jakarta: PT INDEKS.

Kuswanto. 2011. "Observasi (Pengamatan Langsung di Lapangan) (http://klikbelajar.com/-umum/observasi-pengamatan-langsung-dilapangan/). Diakses pada hari Senin tanggal 20 Maret 2017 Pukul 13.55 WIB.

Maryadi, dkk. 2011. Pedoman Penulisan Skripsi FKIP. Surakarta: Badan Penerbit FKIP Universitas Muhammadiyah Surakarta.

Miles, Mathew B. dan Michael A. Huberman. 1992. Analisis Data Kualitatif Buku Sumber tentang Metode-Metode Baru. Jakarta: UIP.

Moleong, Lexy J. 2007. Metodologi Penelitian Kualitatif. Bandung: CV Remadja Rosdakarya. 
Mulyana, Deddy. 2011. Komunikasi Lintas Budaya. Bandung: Rosda Karya

Mulyasa. 2011. Manajemen Berbasis Sekolah, Konsep, Strategi dan Implementasi. Bandung: PT Remaja Rosdakarya.

Nawawi, Hadari dan Martini Hadari. 1992. Instrumen Penelitian Bidang Sosial. Yogyakarta: Gadjah Mada University Press.

Ningsih, Tri Retno. 2015. "Muatan Materi Pancasila sebagai Pandangan Hidup Bangsa dan Pelaksanaanya dalam Proses Pembelajaran (Analisis Isi Buku Pendidikan Pancasila dan Kewarganegaraan pada Siswa Kelas VIII Terbitan Kemendikbud dan Pelaksanaannya di SMP Negeri 2 Gatak Sukoharjo Tahun Pelajaran 2014/2015)”. Skripsi S-1. Surakarta: Fakultas Keguruan dan Ilmu Pendidikan Universitas Muhammadiyah Surakarta.

Rachmawati, Yeni. 2014. "The necessity of multicultural education in Indonesia". Departement of Curriculum Design and Human Potentials Development; National Dong Hwa University

Sugiyono. 2005. Metode penelitian administrasi. Bandung: Alfabeta

Sugiyono. 2010. Metode Penelitian Kuantitatif Kualitatif \& RND. Bandung : Alfabeta

Sugiyono. 2012. Memahami penelitian kualitatif. Bandung: Alfabeta

Sugiyono. 2014. Metode Penelitian Kuantitatif, Kualitatif, dan R\&D. Bandung: Alfabeta.

Sukmadinata, Nana Syaodih. 2011. Metode Penelitian Pendidikan. Bandung: PT. Remaja Rosdakarya.

Syarbaini, Syahrial. 2012. Pendidikan Pancasila (Implementasi nilai-nilai karakter bangsa di perguruan tinggi). Bogor: Ghalia Indonesia.

Tilaar, H.A.R. 2004. Multikulturalisme Tantangan-tantangan Global Masa Depan dan Transformasi Pendidikan Nasional. Jakarta: Grasindo

Türkkahraman, Mimar. 2013. "Social values and value education". Social and Behavioral Sciences 116 ( 2014 ) 633 - 638. doi: 10.1016/j.sbspro. 2014.01.270

Ubaidillah, Abdul Razak A. 2006. Pendidikan Kewargaan (Civic Education) Demokrasi, Hak Asasi Manusia dan Masyarakat Madani. Jakarta: ICCE Uin Syarif Hidayatullah

Winarno. 2013. Pembelajaran Pendidikan PKN (Isi, Strategi, dan Penilaian). Jakarta: Bumi Aksara. 